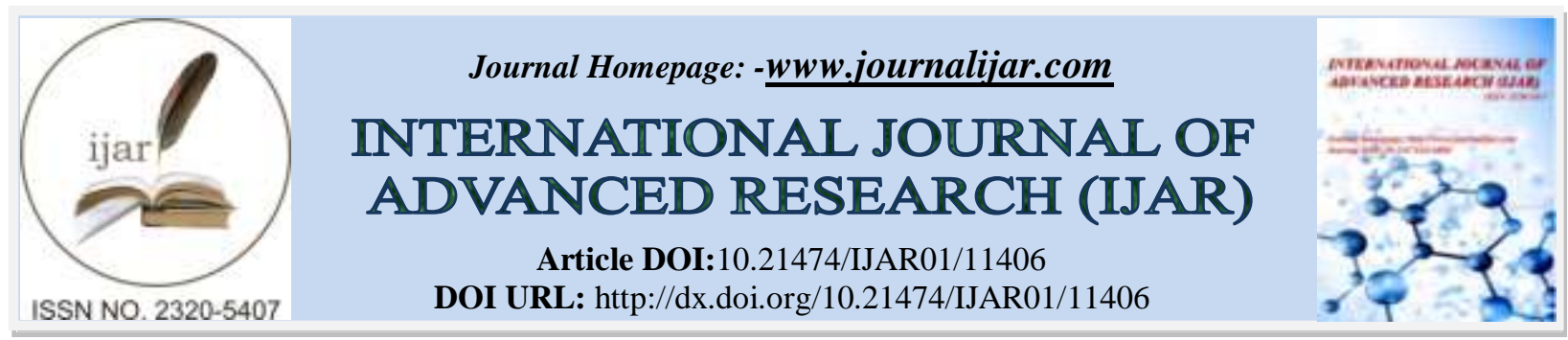

RESEARCH ARTICLE

\title{
FORMULATIVE CRIMINAL POLICY ON SAME SEX INTIMATE RELATIONSHIPS A CRIMINAL
} JUSTICE PERSPECTIVE

\author{
Hendri Yuliwarso SH. MH ${ }^{1}$, Muhadar SH. M.Si ${ }^{2}$ and Dr. Otto Yudianto SH. M.Hum ${ }^{3}$ \\ 1. Doctoral $(\mathrm{PhD})$ Candidate in Law, of the Faculty of Law Universitas 17 Agustus 1945 Surabaya-Indonesia. \\ 2. Emeritus Professor in Law at the Faculty of Law Universitas Hasanuddin, Makasar-Indonesia. \\ 3. Associate Professor in Law at the Faculty of Law Universitas 17 Agustus 1945 Surabaya-Indonesia.
}

\section{Manuscript Info}

Manuscript History

Received: 28 May 2020

Final Accepted: 30 June 2020

Published: July 2020

Key words:-

Same-Sex Sexual Acts, Ciminalization,

Criminal Law, Pancasila

\section{Abstract}

This article has been based on a legal research on the criminalization of obscene acts of same-sex intimate relations. It has been generally observed that the existence of same-sex sexual relations between adults has not been exsited in the legal regulatons. Unregulated withing the Indonesian Legal System in general and in the Indonesian Criminal Justice System in particular. Therefore there has been a strong demand to regulate such acts. In order to understand this phenomena, this research will find answers to questions such as: how is the concept of criminalizing obscene acts of same-sex sexual relations according to the criminal justice perspective. What is the legal reason for the criminalization against obscene acts of same-sex sexual relations. This research is a type of normative legal research, with a focus on searching ratio legis or legal reasons, using philosophical, conceptual approach on the reasons for the criminalization of the same sex intimate relations; as well as, on the formulative criminal policy or the criminalization of same-sex intimate sexual relations between adults to become criminal offenses. It has been found that the criminalization or the formulative policy on the obscene acts of same-sex relations aims at making the deviant behaviour of same sex-oriented to be prohibited in Indonesiam legal system. The way taken in oder to achieve such an objective is by adding the provisions contained in Article 292 of the Criminal Code and Article 420 of the Indonesia Criminal Code. The criminal provision suggested that: "Every adult who is known legally having intend to commit obscene same-sex intimate relationships, or unintentionally carried out in a public place and/in a closed room/with the intention of being published and for any gain should be convicted of a prison sentence of seven years or convicted with a Criminal Code Category V. The same sex act of union done by fellow adults based on like and liking or consent is an act of "taboo", that is not in accordance with religious norms, customs and culture of the Indonesian nation dictates by Pancasila.

Copy Right, IJAR, 2020,. All rights reserved. 


\section{Introduction:-}

The emergence of a legal demands for the state and nation of Indonesia to formulate a criminal or penal policy against the obscene deeds of same-sex intimate relations between adultas has been considered as a very serious problem. It has risen, since there has been a movement of rejecting of the intention to make illegal the same-sex intimate sexual relations or cohabitations.

It has been argued that there are fundamental principle underlining the demand to regulate the same sex intimate relations. The fundamental is namely principle that incompatible with the philosophy of the Indonesian. The Nations has since its conception been a religious nation. It has been crearly stated in the Indonesian Constitution that the Nation is based on the believe of God.

Indonesian Nation recognised the Almighty God. For the Indonesians it is as noble and as moral standard for its laws, as clearly based on the values contained in Pancasila. Pancasila is essentially the highest law of the Nations, a state philosophy/Staatsidee and as a philosophical basic or a philosophy grondslag. The Pancasila that is understood in this writing is the Pancasila that was stipulated in the Preambule of the Indonesian Constitution (UUD 1945). Nothing outside of it.

As it has been stated above, this study aims at analising and discovering the legal reason behind the ideas or concepts of criminal formulative policy or the what so popularly coined as criminalization of the same sex intimate relationships in a perspective of fairness in the criminal law.

There has been no specific definition or meaning given, with regards to the same-sex intimate relations. Its ontological nature has been understood as intimate sexual relations betweeen adults. The intimate sexual relations or sexual acts was mainly having its basis on having the same intentionalities. People at the same age (adults) and having the same sex intent to make a sexual relations, and also having the same desires to obtain sexual satifaction or gratification. These people would then, based on the mutual intentionalities make such a relations (suka sama suka).

From the criminal justice perspective, the above mentioned ontological nature has been regarded as indication of its meaning. However, the meaning is too narow. It means that it does not broad enough to include any actions of obscene acts of sexual relations between adults. The ontological nature of the meaning as mentioned above, has not been compatible with the similar meaning that could be found in Article 292 of the Indonesia Criminal Code.

As it has been generally understood, the Article 292 of the Indonesian Criminal Code was made only to govern the onscene sexual relations between adults and underage. It doses not regulate the sexual relations between adults. Therefore, this has encouraged some section of the Indonesian society to argue that the Article 292 containing an allowance for adults to enjoy same sex relations legally. Adults can obtain sexual pleasures from each other. The Article 292 of the Indonesian Criminal Code only regulated, it could also be arguend, to govern same-sex adult sexual intercourse against minors.

\section{It is stipulated in the Article 292 of the Indonesian Criminal Code that:}

"Orang dewasa yang melakukan perbuatan cabul dengan orang lain sesama kelamin yang diketahuinnya atau sepatutnya diduga belum dewasa, diancam dengan pidana penjara paling lama lima tahun. (Literaly translated: Adults which is making an obscene acts of sexual relations with other people with the same sex who knows or should have known that tha person or that any persons are underage will be punished with five years maximum imprisonment).

If this situation is left out to the understanding as suggested by the section of the Indonesian society as stated above, and that if this problem has not been dealth with properly, it could cause the vagueness of the legal norm. In turn, it could also make the law void when utilised to handell the obscene behaviour between adults of the same sex. These writers believe that the opinion given by the section of the society as mentioned above is a form of the criminal formulation of the Article 292 of the Indonesian Criminal Code that was definitely misleading.

The meaning or ontological nature within the law that must be reconstructed and given as the philosophycal understanding of the Article 292 as stated above, according to these wtiters is as follows. Reading in the context of the broader Indonesian Legal System, the meaning given to the Article 292 of the Indonesian Criminal Code has 
been missunderstood. Puting in the broader context of the Indonesian legal system i.e. the Pancasila legal system, the meaning of the Article 292 of the Indonesian criminal Code must be understood as going against the perseption of the section of the society that it has been construed as to allow or legalizing the same sex mutual relations.

Such a result as mentioned above was the main finding of this research. As mentioned above, it was conducted by using the type of normative legal research. It focused on finding the legal reasons as well as philosophical reasons against the criminalization of same-sex relationships in the policy of formulation or the criminalization of sexual acts of fellow-type relationships of other adults.

The legal materials used in this research was consisting of primary legal materials, secondary legal materials, and tertiary legal materials. The research has mixing up approaches to legislation (statutory approach), conceptual approach, comparative approach to criminal law, philosophical approach.

All approaches have been utilised to examine a legislative policy on the perverting and setting sanctions for the same-sex intimate relationships that has nowadays increasingly exists and penetrate the good values of the Indonesian society, and also Indonesian Nation today.

In this Article, the writers would argue that by criminalization is to mean an attempt to reform the criminal law. The formulative criminal or penal policy has also must be made to determine the nature of the obscene deed of same-sex relationship. The obscene deed of the same sex intimate relations occurs betweeen fellow adults. It has been identified in the Indonesian legal society and its cultural system as becoming the behaviour that stigmatised as obnogsious and deviant sexually oriented deed that is forbidden to exist. The behaviour must have been cosidered as illegal in Indonesia.

It is hoped that the criminalization will produce an order and provisions of criminal law formulated in a fair and sovereign legislation of the Indonesian Legal System (the Pancasila Legal System). With regard to this aspect, the Indonesian law must not depend on the laws of the colonial idea. Therefore the meaning to be formulated, must be a dignified one, it must not or without refering to other nations laws regulating the same aspects, or any other foreign jurisdictions ${ }^{1}$.

\section{On the Pancasila Legal System:}

Indonesia is a sovereign state. Its legal system is based on Pancasila. The legal system has been formed as a unique system of law, called Pancasila Legal System. It is a religious nation system of law that acknowledging the existence of God as reflected in the first tenet (sila), believe in the Almighty God, which holds true religious teachings, customary customs norms and conventions that are reflected in the precepts of Pancasila. Pancasila is the foundation of Indonesia's life in the social and societal life order.

It is always actual, particularly in leading the Indonesian People and Nations State enter in the globalization. As it has been a general knowledge, the globalization has brought about a significant impact on the implementation and understanding of human rights within all kinds of legal terms.

Globalization poses so many problems, and at the time being, rises consern particularly within the milenials and the Indonesian young generation as its future. Many have becomming accustumed or exposed to the idea of free sex, particularly the moral relaxation influenced by the negative use of telecommunicatioan and information technology. One bad influence must be noted, in terms of sexual intercourse outsides marital bound between a man and a woman is a deviant sex-oriented relationship. It has been for the majority considered as taboo, unlawful and against the human nature as God's most perfect creation and noble character.

It is therefore, the same-sex relationship that is a sexual act, and activity that has cause problems. Its turbulence issues and demands on the aspect of the existence or legality. There are types of this taboo, such as having artificial obscene relationship of the same type as one of the legitimate sexual-oriented relations. In addition, there has also

1 This has been long propagated by the Dignified Justice Theory (teori Keadilan Bermartabat), an Indoneian Jurisprudence, developed by Teguh Prasetyo. See, Teguh Prasetyo, Sistem Hukum Pancasila, (Sistem, Sistem Hukum dan Pembentukan Peraturan Perundang-Undangan di Indonesia), Perspektif Teori Keadilan Bermartabat, Cetakan I, Nusa Media, Bandung, 2015. 
other sexual intercourse (heterosexuals). This sexsual taboo cannot be easily accepted so that Indonesia, although Indonesia is also a country that recognizes the full human rights.

Recently emerge various acts of peaceful rallies that demands legality and the recognition of the rights of same sax mutual coexsistence. The rising of the LGBT awarness in the Indonesian society has caused problems as well. These demands have perpetrated the same type of sexual intercourse on the basis of like (suka sama suka). It inflicts a number of conflicts between the pro and those who argue counter to it in the community groups, and directly causes unrest in the life of the people and nation of Indonesia.

In a short terms, the demands and the desire to admit same-sex relations by the state raises a separate polemics. It has been debated whether the deed is very contrary to religious norms and contrary to the values contained in the Pancasila. As it has been mentioned above, Pancasila as the source of all legal sources that also reflects a foundation of the life order of the nation and the people of Indonesia.

Appart from what has already been described above, the community of perpetrators for doing lewd relationships continue to grow. It has been enlarged by the globalisation of the world. It is increasingly people who propagate the obscene acts dare to introduce themselves in social media. There has been propaganda slogans of activities and activities of the organization, the community of their existence.

The activists have been using various media. Now it became increasingly troubling the life order of Indonesia. Indonesia has considering that the matter is not in accordance with the religious norms and cultural norms. The number of national and inter-national events held by the community of sexual acts of lewd relationships in major cities in Indonesia, is certainly a proof that to day Indonesia cannot fully realise the absence of legal norms that govern specifically regarding the aspect.

However, the very long debate among executives, scholars, religious figures, customary leaders, practitioners, academics and jurists on such aspects is a serious problem that must be resolved immediately. Aspects and issues that arise along with progress in the era of globalization require that it is ready and obliged to participate actively in maintaining the norms, values of cultural culture and national ideology of Pancasila.

Lewd relationships of same-sex adults is an act of crime if that is viewed from the juridical aspect. The behaviour is clearly the behaviour and deed that is very abusive and violates the provisions expressed and implied in the Pancasila, as the highest law of the land. It violates the first, and the second paragraphs of the 1945 Constitution. It is in contrary to the paragraph IV, article 29 , article $28 \mathrm{~B}$ and article $28 \mathrm{~J}$, and also Article 1 of the Republic of Indonesia's Act No. 1 issued on 1974 concering Marriage. It also violates the legal provisions stipulated in the article 292 of the Indonesia Criminal Code. However, the rule only governing acts of violating decency with a child categorized under the age of 18 years, of the same gender.

As the stipulated above, it has been a long been polemic on the idea to criminalize the obscene deeds of same-sex fellow adults, therefore the research has also found that the issue must be dealth with as a top priority in efforts to reform national criminal law. The reform must be based on the philosophy of the nation of Indonesia, as the state of Pancasila. In accordance with the provisions of article 292 of the Criminal Code, then can be understood that there is a legal void in the legality arrangement of obscene deeds of same-sex fellow adults on the basis of like (suka sama suka).

As the movement of the community people are cosidered the same sex relations between adults as illegal in Indonesia. Therefore, the crimminalization of same-sex acts is a concept has been formulated and defined in the New Criminal Code Bill (RKUHP). This new formulation would become the basis and the main foundation in the effort to provide a written legal certainty that states the deed and aspect is forbidden in Indonesia and not recognized its existence in Indonesia (illegal). This new formulation of the criminal act could certainly cohers with all of the writers idea stated here and tehre in this article that there must be an additional meaning atteached to the existing Indoneian Crimina Code.

Despite things that has been elaborated above, there has also found in many related legislation, the illegality of such an act. Some might also be found in the law of the Republican states of Indonesia in 1945; Law No. 1 year 1946 on criminal law regulations; Law Number 1 year 1974 about marriage; Law number 8 year 1981 about criminal Events; 
Law number 39 year 1999 on human Rights; Law number 44 year 2008 about pornography; Law number. 36 Years 2009 About Health; Presidential Decree No. 181 of Komnas HAM.

\section{Criminalization of Obscene Deeds:}

Within all of the abovementioned laws, the criminalization of same-sex sexual intercourse is a concept that makes a deed that was not a criminal deed to be come deed to be punished by the law. The rationale underlying the criminalization of sexual intercourse of fellow adult people on the basis of the same likes (free consensual) appears and arises from an organized science based on observation and test results that try to combine between two components of Science and religion.

Science and religion must be in line, interrelated and mutual need. While the science and religion contradicts and runs on their own, there will be great negative effects, such as wrath, perdition, destruction and destruction. Science, in this case to include the law, or the Indonesian Criminal Code and laws will really have the benefits and priorities when guided by religious values on this issue.

The basic concept of criminalization also pays attention to the rights of sexual acts of the same sex. Since criminalization in this case constitutes a criminalization of the same sex deed. It must not be formulate to criminalize the people. The law only forbid the act, sexual intercourse, that is prohibited in Indonesia. But the individual who belongs to the perpetrator of obscene deeds of same-sex relationship is still gaining human rights as an Indonesian citizen. It agrees with the Dignified Justice Theory, which propose that the purpose of the Law, including in this case the law that regulate the same sex behaviour is to humanise human (nguwongke uwong) ${ }^{2}$.

The method of criminalization of lewd deeds of same-sex fellow adults on the basis of consen or like is as mentioned above, to seek to redesign the arrangement of the criminal provision (delict), conduct of same-sex relationships in the Criminal Code (KHUP) in the RKUHP. Also, it must pay attention to arrangements of criminal sanctions deeds of same-sex relationship with the perspective of criminal sanctions penalties and or/penalties with appropriate category of penal sanctions.

Therefore the concept of criminalization of lewd relationships of same-sex fellow adults on the basis of cosnet must also be analyzed in the perspective, as stated above in the idea of justice. It could be argued that this concept of criminalization is therefore based on theory of justice. It analising the concept of criminalization based on the theory of the purpose of criminal sanction.

Starting from the idea of setting the rights and freedoms of society using the criteria of fairness, indicating that in humans, there is a feeling of justice that brings people to an assessment of the factors that play a role in the formation of the law. Principles of fairness can be referred to as legal principles or legal ideas, it is in accordance with the teachings of Immanuel Kant reveals that, "the highest justice is the greatest injustice."

In other words absolute justice is the manifestation of the manifestation of injustice. In a less opinionated setting, which among other things is postulated that the traffic police are the law, because all of them we areto be obeyed, then we find the sense of justice from the sense of the law. On the basis of this, the criteria of principles of justice, is fundamental, as all countries in the world always try to apply the principles of justice in the formation of the law.

Teguh Prasetyo states that "Justice, benefit, and legal certainty as the three basic legal ideas", they are the three in one fundamental values and purposes of the law ". The law, according to this theory must contain these three principles, and should not be difficult to establish simultaneously, to uphold the one, it must not defeat/sacrifice the other. This Dignified Justice is different to the idea of justice expresed by Gustav Radbruch's, whose opinion is as expressed by Bismar Siregar stating: To uphold justice, I sacrifice legal certainty, I will sacrifice the law, because the law is merely a means, while its purpose is justice.

Now relating to and aspects of the deed of sexual intercourse of the same type of adults in the criminal Code it is the expected that while waiting for the New Indonesian Criminal Code to become law, as an urgency measure it must be solved by the what so called rechtsvinding (Penemuan Hukum). By utilising "the judge made law" method, which is

\footnotetext{
${ }^{2}$ See the jurisprudence or the philosophy of law in Teguh Praetyo, Keadilan Bermartabat: Perspektif Teori Hukum, Cetakan I, Nusa Media, Bandung, 2015.
} 
also recognised in the Pancasila Legal System, the penal Code stipulated in the Law No. 1 of 1946 must be interpret justly, humanely when it comes to try the problem of ciminal dimenton arising out of the same sex intimate relations and cohabitations.

It is therefore, the recent ratio legis behind the criminalisation of the obscene deed of same-sex relationship which argued that it has not been regulated, must be countered with the idea that the Indonesian Criminal Code will not tolerate such an obschene acts. One could also take the principles in the Act regulating the prohibition of pornographic acts; and support, by using the rechtsvinding to attach the meanin clearly formulated in article 420, or the 292 of the existing Indonesian Criminal Code and the ideas in the New Criminal Code Bill. As generally understood, thes articles have undergone renewal with article 495 through the criminal formulative policy via judge made law, that the act must not be done publicly. It should also not be done for the sake of commercial use.

Therefore it should, in the formulation of the New Criminal Code Bill must be clearly stated provision regarding prohibition of the obscene deeds of same-sex relations. In other words the prohibition in Indonesia must be using the provisions of criminal threats that has been formulated in the Indonesian nation's spirit of law protection of based on the philosophy of the Indonesian people, which is Pancasila as the highest law of the Land.

The theoretical basis of criminal criminalization of same-sex relationships is a response by the state of an eviljudged deed because it is interpreted as the institutionalization of crimes, so that the Legis Ratio in this aspect arises because of the absence of the law vacuum (rechtsvacuum) and the vacancy norm (vacuum of norm) so that with the efforts of the Law of Discovery (rechtsvinding) is an effort that can be done in overcoming the Void of law and the establishment of legislation based on law No. 12 years 2011) affirmed that "the planning of legislation is conducted in a national legislation Program (Prolegnas).

\section{Conclusion:-}

The criminalization of the same type of sexual intercourse aims to make such acts as a deviant sex-oriented deed that is forbidden in Indonesia by adding an ontological legal meaning to the provisions contained in article 292 of the criminal Code and article 420 RKUHP. Hence the ontological legal meaning to the concept offered as follows: Every adult under the Indonesian Criminal Laws Jurisdiction that is known lawfully/manifestly and intends to commit obscene acts of fellow-sex intercourse persons, intentional and/or accidental committed in public places and/in a closed room/with the intention of being published and to profit sentenced must be considered as a crimina act. Such a criminal act or delik is subject to seven years imprisonment or sentenced to penalty category V; this idea is appears to be in line with the new idea as mentioned in the New Indonesian Criminal Codes.

Same-sex obscene deeds done by fellow adults, sould be consider as on the same basis, in the esence is also the act of "taboo" that is not in accordance with the norm of religion, customs and culture of the Indonesian nation as the eastern people who are guided by the philosophy of Pancasila.

Based on the conclusion then hopefully this research can be beneficial for the institution of the executive, judiciary and legislation in designing, formulating and adding provisions of article 292 criminal Code, by adding obscene deeds of the relationship of fellow crimes based on the norms of religion, customs, and the Indonesian philosophy as the main basis of providing legal policy.

\section{Bibliography:-}

1. Andi Hamzah, Sistem Pidana dan Pemidanaan Indonesia, Pradnya Paramita, Jakarta: 1993;

2. Andi Zaenal Abidin, Asas-asas Hukum Pidana Bagian Pertama, Alumni, Bandung, 1987;

3. Bambang Poernomo, Asas-asas Hukum Pidana, Ghalia Indonesia, Jakarta, 1978;

4. Adami Chazawi, Pelajaran Hukum Pidana. Raja Grafindo. Jakarta. 2011;

5. Adami Chazawi. Stelsel Pidana, Tindak Pidana, Teori-Teori Pemidanaan \& Batas Berlakunya Hukum Pidana.: Raja Grafindo Persada. Jakarta, 2010;

6. Adian Husaini, Seputar Paham Kesetaraan Gender, Adabi Press, Depok : 2012;

7. C.S.T. Kansil dan Christine S.T. Kansil, Pokok-pokok Hukum Pidana, Pradnya Paramita, Jakarta, 2004;

8. Clarkson, Christopher M.V. Understanding Criminal Law. London: 1998. Suveat and Maxwell;

9. Colin Spencer, Sejarah Homoseksualitas dari Zaman Kuno hingga Sekarang, diterjemahkan oleh Ninik Rochani Sjams,: Kreasi Wacana, Bantul 2011, cet ke-2; 
10. Hans Kelsen, General Theory of Law and StateHarvard University Press, New York, 1991;

11. Ibnu Artadi, Menggugat Efektivitas Penerapan Pidana Penjara Pendek Menuju Suatu Proses Peradilan yang Humanis, Jurnal Hukum Pro Justitia, Oktober 2006, Vol. 24 No. 4;

12. J. E. Sahetapy dan B. Mardjono Reksodipuro dalam A.Gumilang, Kriminalistik, Pengetahuan tentang Teknik dan Taktik Penyidikan, Angkasa, Bandung, 1993;

13. M. Yahya Harahap, Pembahasan Permasalahan dan Penerapan KUHAP, Penyidikan dan Penuntutan, edisi kedua,: Sinar Grafika. Jakarta, 2004;

14. Muhadar dan Otto Yudianto, Penjelasan dan pencerahan juga penjabaran tentang peranan/fungsi hukum piadana dalam sesi memberikan tanggapan, Sidang Ujian MKPD I dan II Hendri Yuliwarso, di gedung Fakultas Hukum Lt.II pada tanggal 05 September 2019. Pukul 16.20 WIB;

15. Muladi dan Barda Nawawi Arief "Teori-Teori dan Kebijakan Pidana", Alumni, Bandung,1984;

16. Muladi dan Barda Nawawi Arief. Teori-teori dan Kebijakan Pidana. Alumni. Bandung. 1998;

17. Teori-Teori dan Kebijakan Pidana, Alumni, Bandung, 2010;

18. Muladi, Lembaga Pidana Bersyarat, cetakan ketiga, Alumni, Bandung, 2005;

19. Mulyatno, Asas-asas Hukum Pidana, Gajah Mada University Press, Yogyakarta, 1980;

20. O.Notohamidjojo, Soal-Soal Pokok Filsafat Hukum, Griya Media, Salatiga: 2011;

21. Otto Kirchheimer, Political Justice: The Use of Legal Procedure for Political Ends, Princeton University Press, 1961;

22. Otto Yudianto, Kebijakan Formulatif terhadap Pidana Penjara Semumur Hidup dalam rangka Pembaharuan Hukum Pidana Indonesia, Cetakan I, Menuju Insan Cemerlang, Surabaya, 2015;

23. P. A. F Lumintang, Dasar-Dasar Hukum Pidana Indonesia. cetakan 2 Sinar Baru. Bandung. 1990;

24. P.A.F. Lamintang, Dasar-Dasar Hukum Pidana Indonesia, Sinar Baru, Bandung: 1984;

25. R.Susilo. Kitab Undang-Undang Hukum Pidana, Politelia, Bogor.1995;

26. Rusjdi Ali Muhammad, Hak Asasi Manusia dalam Perspektif Syariat Islam, cet. 1 Ar-Raniry Press dan Mihrab, Banda Aceh: 2004.

27. Sudarto, Hukum Pidana dan Perkembangan Masyarakat: Kajian Terhadap Pembaharuann Hukum Pidana, Sinar Baru, 1983;

28. Teguh Prasetyo dan Abdul Halim Barkatullah, Filsafat, Teori, dan Ilmu Hukum, Pemikiran Menuju Masyarakat yang Berkeadilan dan Bermartabat, Raja Grafindo Persada, Jakarta, 2012;

29. Kriminalisasi dalam Hukum Pidana, Nusa Media, Bandung, 2010;

30. Kriminalisasi dalam Hukum Pidana, Nusa Media, Bandung, 2011,;

31. Sistem Hukum Pancasila, (Sistem, Sistem Hukum dan Pembentukan Peraturan Perundang-Undangan di Indonesia), Perspektif Teori Keadilan Bermartabat, Cetakan I, Nusa Media, Bandung, 2015;

32. Van Hamel dalam Satochid Kartanegara, Hukum Pidana Bagian Pertama, Balai Lektur Mahasiswa, Jakarta, 1955 ;

33. Von Savigny dalam Abdul Manan, Aspek-aspek Pengubah Hukum, Prenada Media, Jakarta, 2005;

34. W. Friedmann, , The State and The Rule of Law in Mix Economy, Steven \& Son, London: 1971;

35. Mansur Fakih. Analisis Gender \& Transformasi Sosial. Pustaka Pelajar, Yogyakarta, 1996. 